Original Research Paper

\title{
Presence of the Barbary Sheep (Ammotraguslervia) in the region of Illizi (Southeast Algeria)
}

\author{
Irzagh A. ${ }^{1}$, Derouiche L. $^{2}$, Benrima A. ${ }^{1}$ \\ ${ }^{1}$ Saad Dahlab University Blida, Blida, Algeria. \\ ${ }^{2}$ Higher School of Food Sciences \& Agrifood Industries, Algiers, Algeria.
}

Corresponding Author: Irzagh Ahmed, Saad Dahlab University Blida, Blida, Algeria.

E-mail: irzagh_ahmed@yahoo.fr

Article history; Received: July $7^{\text {th }} 2021$; Revised: August $30^{\text {th }} 2021$; Accepted: December $2^{\text {nd }} 2021$

\begin{abstract}
The Barbary sheep (Ammotragus lervia), which is sometimes referred to as Aoudad, is widely spread in different parts of Africa as an endemic species, while in Europe and America it is an introduced species. This animal is protected by the decrees of the International Union for Conservation of Nature (IUCN) as well as by the laws of several countries, including Algeria. In order to conserve the Barbary sheep in its natural environment, it was decided to carry out this work which is in fact an update of the knowledge on the presence of the Barbary sheep in the region of Illizi (southeast of Algeria). To do this, surveys were carried out on 20 transects during the years 2015 and 2016 in the region of Illizi (southeastern Algeria) in order to identify populations of wild ungulates, in particular Ammotragus lervia. These transect surveys led to finding a number that exceeds 131 animals divided into 30 females, 43 males and 19 young individuals. In addition, 39 individuals who were observed from afar, and therefore it was not possible to clearly determine their se $\mathrm{x}$. However, the nature of their habitats could be identified. It should also be recognized that the Barbary sheep (Ammotragus lervia) is a species that is seriously threatened by the risk of poaching.
\end{abstract}

Keywords: Ammotragus lervia; Populations; Prospects; Illizi; Algeria.

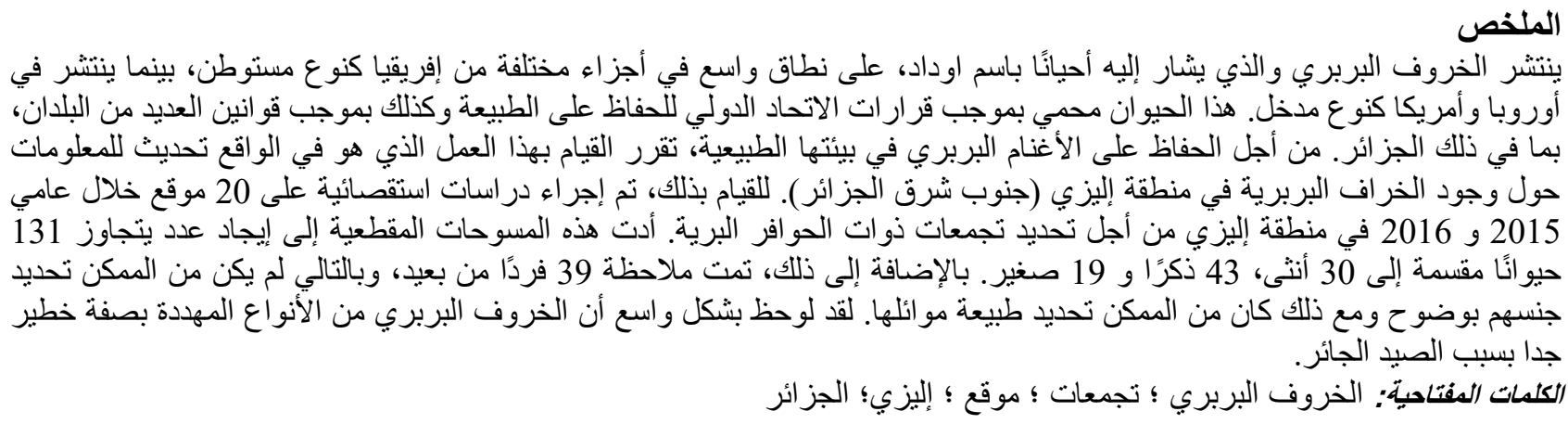




\section{Introduction}

The Barbary sheep (Ammotragus lervia Pallas, 1777) is a large herbivorous mammal of the Tribe Caprini. It is an indigenous species of the mountains of North Africa and the rocky regions of the Sahara that extend from the Atlantic Ocean to the Red Sea (Cassinello, 2013). This animal has disappeared from much of its original range; the populations of this species are relatively important only in Morocco, in the nature reserves of Aïr and Ténéré in Niger, Hoggar, Tassili n'Ajjer in south-eastern Algeria, Adrar des Iforas, and central Mauritania (Cassinello, 2013). It has been successfully introduced in Europe, i.e. Spain and France, and in North America, particularly in New Mexico, Texas, and California (Valdez, 2011; Cugnasse, 2014).

The Barbary sheep was already present in Algeria in the Pleistocene fauna of the region of Beni Segoual (Arambourg et al., 1934). From the middle of the 19th century until the beginning of the 20th century, French colonization in Algeria (1830 -1962) facilitated the study of this species by Europeans in the Saharan Atlas, the Aures and neighboring regions of the Sahara as well as in the mountains which plunge further south (Rothschild, 1913). Many researchers have studied the distribution of Ammotragus lervia in Algeria. Joleaud (1928) gave a detailed description of the northern limit of its distribution. The range of this animal includes the mountains of Sidi Abid on the border with Morocco, at the northern limit of the Highlands, and the mountains of Ouenza, north of Tebessa. In addition, the southern region includes all the major mountainous and rocky parts of the Algerian Sahara. It should be noted that Barbary sheep also live on the slopes of Wadis, far from the mountains. It was also found that the Barbary sheep is present in the region of Ain ben Khelil in the east, and on the side of the northern limit of the Saharan Atlas, extending further north into the mountains of the Aures. On the other hand, Heim De Balsac (1936) reported new information indicating its presence in parts of the Hoggar and Tanezrouft mountains. In addition, Kowalski \& Rzebik Kowalska (1991) reported its presence in Ain El Hadjadj, in the southern part of Tademait, in Assekrem in Hoggar, and in Tamrit in Tassili n'Ajjer (in the southeast of the Algeria).

According to Cassinello (2013), Algeria hosts two subspecies of Barbary sheep: A. lervia Lervia in the north and west and A. lervia sahariensis in the south. A recent genetic study confirmed the old divergence of two lines corresponding to these two subspecies (Derouiche et al., 2020). A. Lervia Lervia is still present in very low numbers in four places in the mountains of the northeast, south of Tebessa, Batna, M'Sila and northeast of Biskra, and west to south of Tiaret and in the Bechar region (Kowalski \& Rzebik-Kowalska, 1991; Bounaceur et al., 2016). In southern Algeria, A. lervia sahariensis is older known from Tassili n'Ajjer, Mouydir, Tefedest and Hoggar, with a probability of being present in the southern part of the Tademait plateau (Kowalski \& Rzebik-Kowalska, 1991). However, the region of Illizi, in southeastern Algeria, still remains a poorly explored area. Therefore, the purpose of this study is to fill this gap and contribute to the conservation of this species in its original habitat.

\section{Material and methods}

The region of Illizi is located in the extreme southeastern part of Algeria (Figure 1), with latitude coordinates: $24^{\circ} 33^{\prime} \mathrm{N}$, and longitude coordinates: $9^{\circ} 29^{\prime} \mathrm{E}$. In addition, Illizi is located at an altitude of $1094 \mathrm{~m}$ and at a distance of $2200 \mathrm{~km}$ from the capital Algiers (Dubief, 1999). The average annual precipitation of the region is estimated at $1.15 \mathrm{~mm}$. Its rainfall quotient makes it possible to place the study region in the Saharan bioclimatic stage.

As part of this study systematic field trips were organized, at the frequency of one field trip per month, during which 20 transects, characterized by different altitudes and soil type, were surveyed (Table 1). These transects were selected according to the topography and geomorphology of the areas in order to cover the majority of habitats that can accommodate the Barbary sheep, in particular the bottom of valleys and Wadis, and all rugged terrain. 


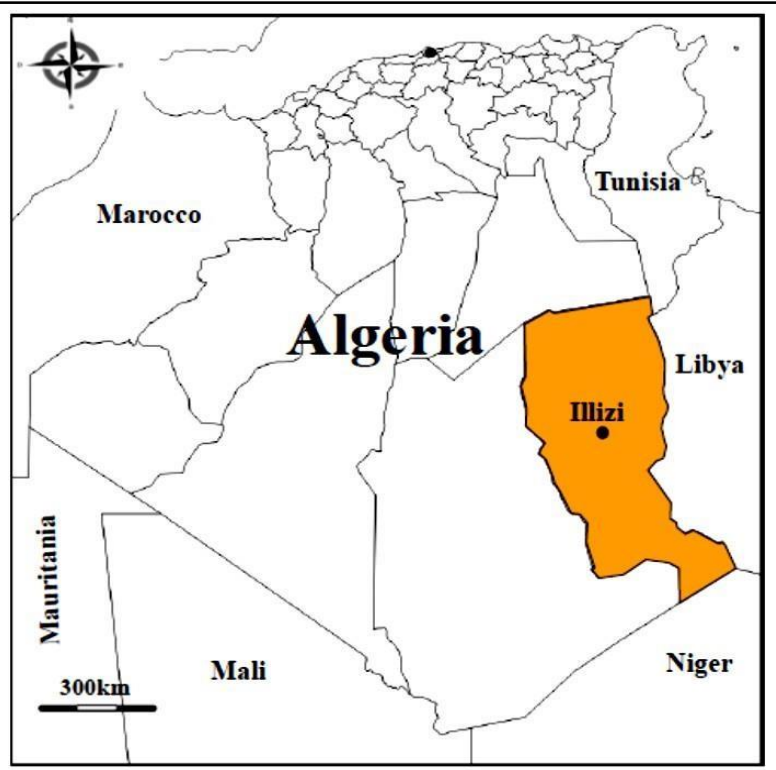

Figure 1. Geographical location of the Wilaya of Illizi in Algeria.

Table 1: Location of the prospected transects in the region of Illizi (Algeria), with the altitude and type of soil.

\begin{tabular}{|c|c|c|c|c|}
\hline Transect & Locality & Coordinate & Altitude (m) & Type of soil \\
\hline $\mathrm{T} 1$ & Oued Sersouf & $24^{\circ} 57^{\prime} 32.1^{\prime \prime} \mathrm{N}, 08^{\circ} 46^{\prime} 49.9^{\prime \prime} \mathrm{E}$ & 1147 & Wet sandy \\
\hline $\mathrm{T} 2$ & Oued Tessdamarene & $24^{\circ} 53^{\prime} 46.1^{\prime \prime N}, 08^{\circ} 48^{\prime} 09.2^{\prime \prime} \mathrm{E}$ & 1224 & Sandy \\
\hline T3 & Oued Tikoubaouine & $24^{\circ} 48^{\prime} 09.4^{\prime \prime} \mathrm{N}, 09^{\circ} 05^{\prime} 47.4^{\prime \prime} \mathrm{E}$ & 1146 & Dry sandy clay \\
\hline T4 & Oued Imourouden & $24^{\circ} 39^{\prime} 14.3^{\prime \prime N}, 09^{\circ} 13^{\prime} 41.9^{\prime \prime} \mathrm{E}$ & 1190 & Rocky sand \\
\hline T5 & Oued Alghou & $24^{\circ} 54^{\prime} 17.4^{\prime \prime N}, 08^{\circ} 57^{\prime} 52.4^{\prime \prime E}$ & 1154 & Sandy \\
\hline T6 & Oued Abichoal & $24^{\circ} 54^{\prime} 58.3^{\prime \prime} \mathrm{N}, 08^{\circ} 56^{\prime} 36.5^{\prime \prime} \mathrm{E}$ & 1139 & Wet and clayey \\
\hline $\mathrm{T} 7$ & Oued Essendilen & $24^{\circ} 55^{\prime} 50.6^{\prime \prime N}, 08^{\circ} 58^{\prime} 59.7^{\prime \prime E}$ & 1146 & Wet \\
\hline $\mathrm{T} 8$ & Oued Tellaline & $24^{\circ} 46^{\prime} 41.2^{\prime \prime} \mathrm{N}, 09^{\circ} 08^{\prime} 00.8^{\prime \prime} \mathrm{E}$ & 1147 & Rocky and dry sandy \\
\hline T9 & Oued Tilafzou & $24^{\circ} 41^{\prime} 03.1^{\prime \prime N}, 09^{\circ} 13^{\prime} 50.0^{\prime \prime E}$ & 1146 & Dry sandy \\
\hline T10 & Oued Tiharmouine & $24^{\circ} 35^{\prime} 13.0^{\prime \prime} \mathrm{N}, 09^{\circ} 19^{\prime} 39.7^{\prime \prime E}$ & 1168 & Rocky sand \\
\hline T11 & Idukal 2 & $24^{\circ} 18^{\prime} 36.8^{\prime \prime N}, 10^{\circ} 48^{\prime} 37.8^{\prime \prime E}$ & 1035 & Dry sandy \\
\hline T12 & Indjerren & $24^{\circ} 03^{\prime} 44.7^{\prime \prime} \mathrm{N}, 11^{\circ} 01^{\prime} 44.3^{\prime \prime} \mathrm{E}$ & 998 & Dry sandy \\
\hline T13 & Wan Zawten 1 & $24^{\circ} 05^{\prime} 16.1^{\prime \prime N}, 10^{\circ} 54^{\prime} 24.8^{\prime \prime E}$ & 925 & Dry sandy \\
\hline T14 & Wan Zawten 2 & $24^{\circ} 10^{\prime} 54.0^{\prime \prime} \mathrm{N}, 11^{\circ} 00^{\prime} 43.1^{\prime \prime} \mathrm{E}$ & 925 & Dry sandy \\
\hline T15 & Wan Zawten 3 & $24^{\circ} 05^{\prime} 26.6^{\prime \prime N}, 10^{\circ} 57^{\prime} 22.2^{\prime \prime E}$ & 925 & Dry sandy \\
\hline T16 & El Baredj & $23^{\circ} 58^{\prime} 21.4^{\prime \prime} \mathrm{N}, 10^{\circ} 55^{\prime} 50.2^{\prime \prime} \mathrm{E}$ & 2902 & Dry sandy \\
\hline $\mathrm{T} 17$ & Tahort & $24^{\circ} 23^{\prime} 06.7^{\prime \prime} \mathrm{N}, 09^{\circ} 08^{\prime} 06.5^{\prime \prime} \mathrm{E}$ & 1011 & Rocky \\
\hline T18 & Tisnar & $24^{\circ} 05^{\prime} 29.9^{\prime \prime} \mathrm{N}, 09^{\circ} 00^{\prime} 25.1^{\prime \prime} \mathrm{E}$ & 943 & Rocky \\
\hline T19 & Tin Arkni & $23^{\circ} 24^{\prime} 44.0^{\prime \prime} \mathrm{N}, 08^{\circ} 23^{\prime} 39.4^{\prime \prime} \mathrm{E}$ & 886 & Rocky \\
\hline T20 & Tanet & $24^{\circ} 33^{\prime} 05.0^{\prime \prime} \mathrm{N}, 07^{\circ} 35^{\prime} 58.0^{\prime \prime} \mathrm{E}$ & 887 & Rocky \\
\hline
\end{tabular}

Like all animals living in the desert, the Barbary sheep are active during the cooler hours of the day, at dawn or dusk; during the hottest hours of the day, it rests in the shade of a rock. For this reason, our prospecting day was divided into two phases. The first phase, which runs from 6 a.m. to 8 a.m., is devoted to direct observation for counting animals and estimating population size, while the second phase, which runs from 8 a.m. to at nightfall, was devoted to the search for signs of the presence of this animal, in particular droppings and footprints, in order to establish the distribution of the species. 


\section{Results and discussion}

\section{The observations of Barbary sheep in the region of Illizi}

The different observations of Barbary sheep are summarized in table 2.

Table 2: Barbary sheep observed classified by transects, total number, sex and age.

\begin{tabular}{|c|c|c|c|c|c|c|}
\hline Transects & Total number & Number of females & $\begin{array}{l}\text { Number of } \\
\text { males }\end{array}$ & $\begin{array}{l}\text { Number } \\
\text { unknown }\end{array}$ & $\begin{array}{l}\text { Number } \\
\text { of adults }\end{array}$ & $\begin{array}{l}\text { Number } \\
\text { of young }\end{array}$ \\
\hline $\mathrm{T} 1$ & 9 & 4 & 5 & - & 9 & - \\
\hline $\mathrm{T} 2$ & 6 & - & - & 6 & 6 & - \\
\hline T3 & 8 & 2 & 6 & - & 8 & - \\
\hline $\mathrm{T} 4$ & 3 plus a group & 2 & 1 & - & 3 & - \\
\hline $\mathrm{T} 5$ & 9 plus a group & 3 & 1 & 2 & 6 & 3 \\
\hline T6 & 10 plus a group & 2 & 5 & 3 & 3 & - \\
\hline $\mathrm{T} 7$ & 8 & 4 & 3 & 1 & 7 & - \\
\hline $\mathrm{T} 8$ & 9 & - & - & 7 & 7 & 2 \\
\hline T9 & 3 & - & - & 3 & 3 & - \\
\hline T10 & 12 & 6 & 6 & - & 12 & - \\
\hline T11 & 3 & - & - & 3 & 3 & - \\
\hline T12 & 4 & 2 & 1 & - & 3 & 1 \\
\hline T13 & 7 & - & 7 & - & 7 & - \\
\hline T14 & 6 & - & - & 6 & - & - \\
\hline T15 & 5 & - & 3 & 2 & 5 & - \\
\hline T16 & 6 & 1 & 3 & - & 4 & 2 \\
\hline $\mathrm{T} 17$ & A group & - & - & - & - & - \\
\hline T18 & 18 & 2 & 1 & 4 & 7 & 11 \\
\hline T19 & 3 & 2 & 1 & - & 3 & - \\
\hline $\mathrm{T} 20$ & 2 & - & - & 2 & 2 & - \\
\hline Total & 131 & 30 & 43 & 39 & 98 & 19 \\
\hline
\end{tabular}

It is worth indicating that, out of the 20 transects in the region of Illizi, a total of 131 observations of Barbary sheep were recorded, with 30 females, 43 males and only 19 young individuals. In addition, it should be noted that 39 individuals were observed from afar without being able to determine their sex.

In addition to these 131 sightings, footprints and droppings of large groups of mouflon populations were noted (Figure 2).
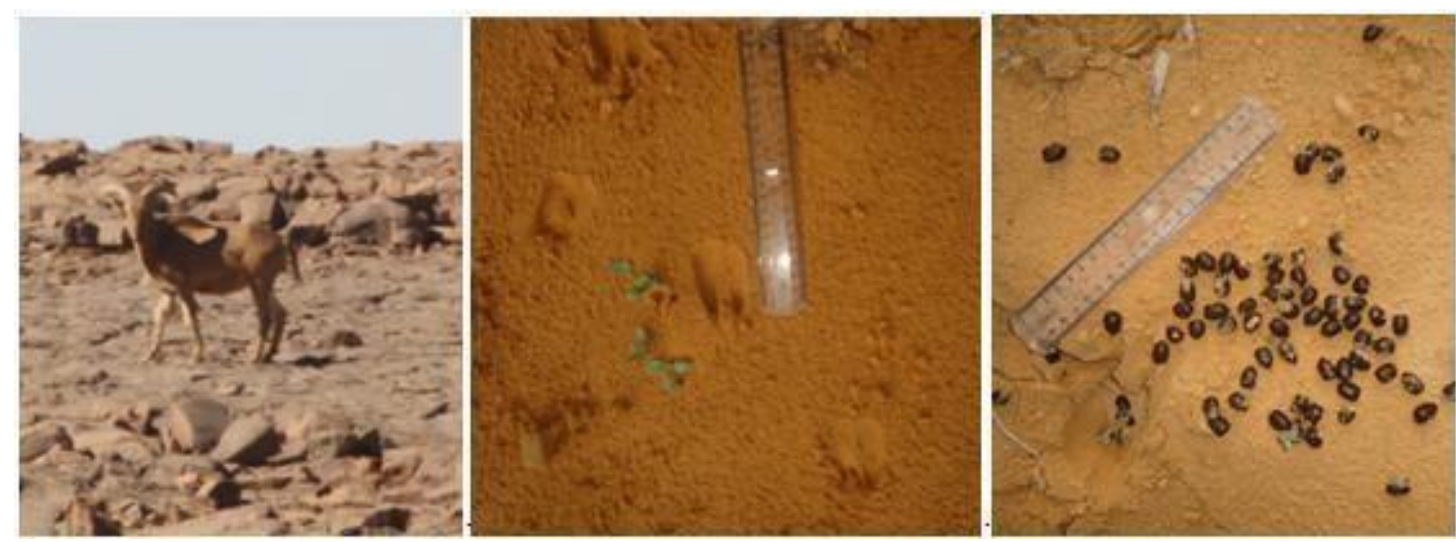

Figure 2. Prospecting by direct observation of the mouflon or follow its tracks (footprints and droppings). 


\section{The Barbary sheep subspecies found in the region of Illizi}

Among the six subspecies of the mouflon, the observed specimens all represent the Sahara mouflon, which is the subspecies Ammotragus lervia sahariensis (Rotschild, 1913). This subspecies is characterized by a very large geographic distribution (Gray \& Simpson, 1985). Indeed, this subspecies is found in parts of southern Morocco and Western Sahara (Aulagnier \& Thévenot, 1997), the Sahara of southern Algeria (De Smet, 1997b), southern Tunisia, southeastern Libya (Shackleton \& De Smet, 1997), Sudan and Mali (Lamarche, 1997a), Niger, Mauritania and in the Tibesti mountains (Lamarche, 1997b). This subspecies is also found in Chad (Mekonlaou \& Daboulaye 1997; Alados, 1988). Today, it is probably restricted to the sandstone massifs of the Ennedi only (Mekonlaou \& Daboulaye, 1997). The work of Cassinello (2008, 2012, 2013) confirms the results cited above. Indeed, he located Ammotragus lervia sahariensis in southern Morocco, in the Algerian Sahara (Tassili - Hoggar / A'haggar massif), in southwest Libya, in northern Mauritania and Mali (Adrar des Iforas), in the Tibesti and Air massifs (Niger), and on the border between Chad and Sudan. It should be mentioned that our work accurately confirms the existence and current distribution of populations of this subspecies in the region of Illizi in southeastern Algeria.

\section{Barbary sheep habitat}

The Barbary sheep inhabits rocky and steep regions located at altitudes between 200 and $4100 \mathrm{~m}$. In addition, it exhibits a clear reluctance for snow-covered areas (Cassinello, 1997). This animal uses space depending on the season and in accordance with the habitat in which it has been introduced. Moreover, in winter it generally seeks warmer south-facing slopes, while in summer it prefers the fresher northern slopes which are ordinarily covered with better pastures. It also favors more open and sloping areas during the breeding season of spring, wooded areas in summer, and pastures in autumn (mating) and winter (Croquet \& Cugnasse, 2013; Cassinello, 2012). It is worth noting that in southern Algeria, and particularly in the region of Illizi which is characterized by a fairly original geology, the habitat of this animal is selected according to the peculiarities of the region. It should be noted that this type of sheep was particularly located in sandy and rocky areas in view of the fact that this animal is exceptionally agile on steep mountain slopes. Indeed, this animal can easily perform $2 \mathrm{~m}$ long leaps in jump step. On the other hand, it can also run at quite high speed over the roughest terrain but always tries to avoid sandy deserts.

The Barbary sheep is the least nomadic of all Bovidae. In fact, their sedentary lifestyle is so high that they live in very protective, steep and very tormented environments, with ravines, cracks, caves, piles of huge boulders, where they can escape their pursuers in a few leaps (Benkheira, 2006).

\section{Biodiversity and threats}

Algeria covers an area of $2381741 \mathrm{~km}^{2}$, stretching from east to west over $1622 \mathrm{~km}$ and from north to south over nearly $2000 \mathrm{~km}$. It is one of the most original countries in the western Palaearctic region from the geographical, climatic and ecological point of view. Furthermore, Algeria is viewed as one of the richest countries in the Mediterranean basin in terms of biological diversity. Indeed, the important ecosystem diversity of this country is mainly due to its bioclimatology as well as to its large geographical area. The combination of all these factors made it possible to generate an even greater environmental variability, which resulted in a richer diversity in terms of the physiognomic vegetation structures, habitats and biotopes, landscapes and natural resources (Abdelguerfi, 2009).

This positive finding should however be moderated because the current situation appears to be less brilliant. Indeed, this exceptional natural wealth has, for several decades, been subjected to the increasing pressures of a rapidly developing society, in addition to the unpredictable vagaries of several years of drought. This natural wealth, which is therefore often subject to serious degradation as is the case in many other countries around the Mediterranean, is now seriouslythreatened. 
It should also be noted that the Algerian mammal population is not immune to these threats. Indeed, Algeria currently has currently108 species of mammals (Stork \& Samways, 1995; Abdelguerfi et al., 2009). With regard to the protection of mammalian fauna, it turned out that of the 108 species of mammals present in Algeria, 47 species, or $43.92 \%$ of the total, are protected by Algerian legislation. However, this list should be revised upwards (Abdelguerfi, 2009). Several of these protected species are distributed in southern Algeria, and more specifically in the region of Illizi. During our field trips, it was possible to observe several species of mammals such as Gazella dorcas, Procavia capensis, Massoutira Mazbi, Aselia tridens, Fennecus zerda, Paraechinus aethiopicus, and Asellia tridens.

It is worth mentioning that one of the most remarkable species observed in the region of Illizi is the Barbary sheep (Ammotragus lervia) whose range and numbers have been significantly reduced due to habitat degradation and also to poaching. It should be noted that today the Barbary sheep is found in small populations in the steppe and pre-desert environments (Benkheira, 2006).

Unfortunately, this animal is now seriously threatened with extinction in its natural environment, although this particular species is protected by the Algerian decree No 83-509 of August 20, 1983 relative to nondomestic animal species protected by law. Indeed, the main threats to the Barbary sheep are poaching and the destruction of its habitat mainly due to overgrazing, wood collection, drought and desertification. For example, hunting by army soldiers in Western Sahara has been a serious threat to this species (Lhafi, 2006). The decline of the subspecies Ammotragus lervia lervia and Ammotragus lervia sahariensis is particularly attributed to intensive poaching. Generally, the Barbary sheep, which formerly infested the heights of Djebel Béchar, Djebel Antar, Farâat Sidi Moumène, the Zouzfana and Taghit plain, has been hunted by poachers with complete impunity and during all seasons (De Smet, 2012). During our field surveys, it was found that the region of Illizi is not safe from poachers (Figure 3).

The conservation of the different species of wild fauna is a huge task for all countries. It requires a lot of time, material and financial resources, and qualified personnel. It should also be noted that the survival of an animal species must be guaranteed in situ. In addition, conservation in ex-situ conditions (biological reserves, hunting centers, protected areas, etc.) is often beneficial for any species in order to avoid its extinction. Therefore, in order to protect it, Algeria has decided to reintroduce the Barbary sheep in two reserves, namely the hunting reserve of Djelfa located in the Hauts Plateaux (34 $39^{\prime} 60.00^{\prime \prime} \mathrm{N}, 3^{\circ} 15^{\prime} 0.00^{\prime \prime}$ E) and the hunting reserve of Tlemcen in the northwestern part of Algeria (34 $4^{\circ} 51^{\prime} 51.95^{\prime \prime} \mathrm{N}, 1^{\circ} 19^{\prime} 23.08^{\prime \prime}$ W).

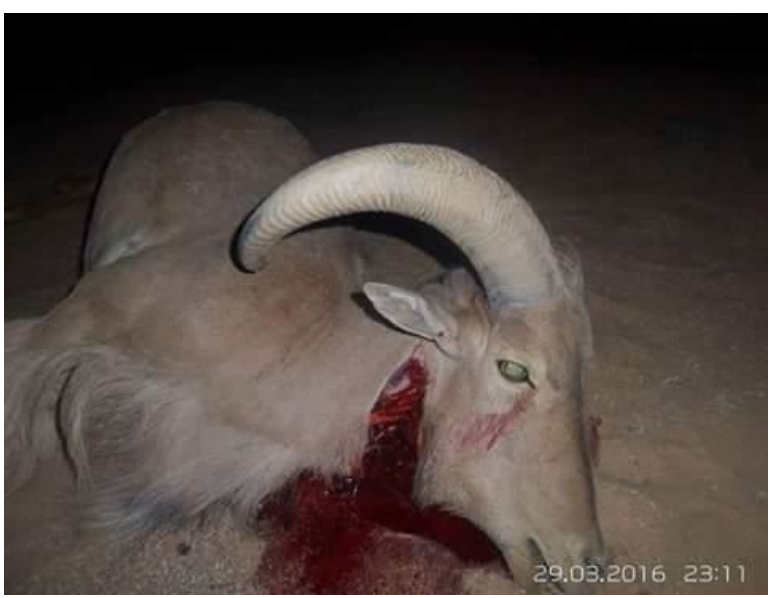

Figure 3. Barbary sheep hunted and slaughtered by poachers. 


\section{Conclusion}

This study found that the Barbary sheep occupies a significant part of the region of Illizi. Demographic monitoring and ecological studies have become more than necessary today in order to better understand these natural populations which inhabit particular areas that are different from those reported in previous studies. The results obtained in this work could contribute to the implementation of a systematic management and conservation planning for this species particularly in this region of Algeria. It should also be added that the actual distribution and abundance of ungulates in the investigated region, especially in the highly anthropized part, depends mainly on the awareness of civil society. Moreover, these ungulates ought to be fully protected by the local population. Besides, local beliefs, awareness, media, environmental education, associative movements, should be sensibilized and encouraged as they can play a fundamental role in the protection and preservation of wild animal species.

\section{References}

Abdelguerfi A. Chehat F. Ferrah A. Yahiaoui S 2009. Quatrième rapport national sur la mise en œuvre de la convention sur la diversité biologique au niveau national. Rapport du Ministère de l'aménagement du territoire, de l'environnement et du tourisme algérien.

Alados CL. Escós J. Vericad JR 1988. Captive populations of northwest African Antilopinae and Caprinae at the Estación Experimental de Zonas Aridas. In: Dixon, A. \& Jones, D. (eds.), Conservation and biology of desert antelopes, Christopher Helm Ltd., Kent, p: 199-211.

Arambourg C. Boule M. Vallois H. Verneau R 1934. Les grottes paléolithiques des Beni Segoual (Algérie). Archives de l'Institut de paléontologie humaine, Paris, Mém., 13, p: 1-242.

Aulagnier S. Thévenot M 1997. Morocco (including Western Sahara). In: Wild sheep and goats and their relatives: status survey and conservation action plan for Caprinae. Ed. by Shackleton, D. M. Gland, Switzerland: IUCN, p: 17-19.

Benkheira A 2006. Specialnaâma, Bull. n ${ }^{\circ}$ 5, D.G.F., p: 14-15.

Bounaceur F. Benamor N. Bissaad FZ. Abdi A. Aulagnier S 2016. Is there a future for the last populations of Aoudad (Ammotragus lervia) in Northern Algeria? Pakistan J. Zool., 48(6), p: 1727-1731.

Cassinello J 1997. High levels of inbreeding in captive Ammotragus lervia (Bovidae, Artiodactyla): Effects onphenotypic variables. Canadian Journal of Zoology, 75, p: 1707-1713.

Cassinello J 2012. Arrui - Ammotragus lervia. Encyclopedia Virtual de los Vertebrados Espanoles.

Cassinello J 2013. Ammotragus lervia Aoudad (Barbary sheep, Arrui). in : J. Kingdon \& M. Hoffmann (eds) : Mammals of Africa. Volume VI. Pigs, hippopotamuses, chevrotain, giraffes, deer and bovids. Bloomsbury Publ., London, p: 595-599.

Cassinello J. Cuzin F. Jdeidi T. Masseti M. Nader I. De Smet K 2008. Ammotragus lervia. In: IUCN Red List of Threatened Species. Version 2013. 2.

Croquet V. Cugnasse JM 2013. Le mouflon à manchettes (Ammotragus lervia, Pallas, 1777) dans la montagne de Sainte-Victoire (Bouches-du-Rhône). ONCFS. 13p.

Cugnasse JM 2014. Le Muntjac de Chine et le Mouflon à manchettes. Faune sauv., 304 : 31 .

De Smet K 2012. La répartition des grands mammifères dans le désert algérien est très mal connue ! Nature Vivante, 10, p: 2-9.

De Smet K 1997. Algeria. In: Shackleton, D. M. (ed.), Wild sheep and goats and their relatives: status survey and conservation action plan for Caprinae. IUCN, Gland, Switzerland, p: 17-19. 
Derouiche L. Irzagh A. Rahmouni R. Tahri R. Hadjeloume M. Bouhadad R. Fernandes C 2020. Deep mitochondrial DNA phylogeographic divergence in the threatened aoudad Ammotragus lervia (Bovidae, Caprini). Gene, 739, 144510.

Dubief J 1999. L'Ajjer Sahara central, Ed. Karthala, Paris, 709p.

Gray GG. Simpson CD 1985. Horn growth and aging of free-ranging Barbary sheep (Ammotragus lervia). Mammalia, 49, p: 85-91.

Harper F 1945. Extinct and vanishing mammals of the old world. Amer. Committee for Int. Wildlife protection, New York. Pub. $\mathrm{N}^{\circ} 12$.

Heim De Balsac H 1936. Biogéographie des mammifères et des oiseaux de l'Afrique du Nord. Supplément XXI au Bulletin biologique de France et de Belgique. Paris, 446p.

Joleaud L 1928. Le mouflon à manchettes in: Contribution à l'étude du peuplement des hautes montagnes. Lechevalier, Paris, p: 35-37.

Kowalski K. Rzebik-Kowalska B 1991. Mammals of Algeria. Polish Acad. Sci. Inst. Syst. and Evol. of Animals, Ossolineum Publishing House, Wroclaw, Poland, p: 17-31.

Lamarche B 1997a. Mali. In: Shackleton, D. M. (ed.), Wild sheep and goats and their relatives: status surveyand conservation action plan for Caprinae: IUCN, Gland, Switzerland, p: 32-33.

Lamarche B 1997b. Mauritania. In: Shackleton, D. M. (ed.), Wild sheep and goats and their relatives: statussurvey and conservation action plan for Caprinae: IUCN, Gland, Switzerland, p: 33-34.

Le Berre M 1990. Faune du Sahara, tome 2, mammifères, Ed. Terres africaines, 360p.

Lhafi A 2006. Manuel pratique pour la gestion cynégétique durable des populations de mouflon à manchette, F.A.O-GCP/MOR/031/CEH, 84p.

Mekonlaou M. Daboulaye BY 1997. Chad. In: Shackleton, D. M. (ed.), Wild sheep and goats and theirrelatives: status survey and conservation action plan for Caprinae. IUCN, Gland, Switzerland p: 1921.

Ogren H 1965. Barbary sheep. New Mexico department of Game and Fish Bulletin 13, Santa Fe.

Rahmouni R. Derouiche L. Belantar I., Gaouar SBS 2019. Morphological and phylogenetic study of the Barbary sheep (Ammotragus lervia) at the Tlemcen hunting reserve. Gen. Biodiv. J., 3(1), p: 20-34.

Rangel-Woodyard E. Simpson CD 1980. Status of Barbary sheep in Mexico. In: Simpson, C.D. (ed.), Symposium on ecology and management of Barbary sheep. Texas Tech. Univ. Press, Lubbock, p: 30-32.

Rothschild W 1913. On Ovis lervia Pallas and its subspecies. Novit. Zool., 20, 459p.

Shackleton DM. De Smet K 1997. Libya. In: Shackleton, D.M. (ed.), Wild sheep and goats and their relatives: status survey and conservation action plan for Caprinae. IUCN, Gland, Switzerland, p: 30-32.

Stork NE. Samways MJ 1995. Inventorying and monitoring biodiversity. Trends in Ecology \& Evolution, 11, p: 39-40.

Valdez R 2011. Aoudad Ammotragus lervia. in: D. E. Wilson \& R. A. Mittermeier (eds): Handbook of the Mammals of the World. 2. Hoofed mammals. Lynx, Barcelona, p: 714-715. 